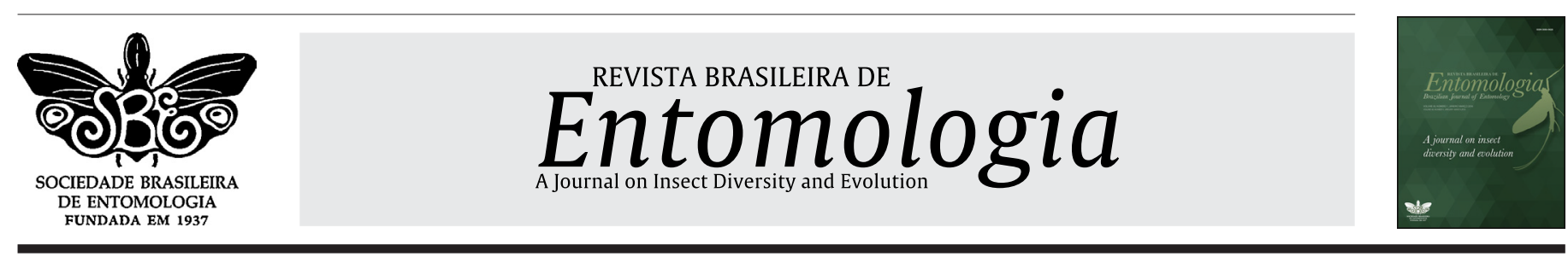

\title{
The morphology of the eggs in the Hermanella complex (Ephemeroptera: Leptophlebiidae)
}

\author{
Thayna da Silva Raymundo ${ }^{1,2 *}$ (D), Jéssica Letícia Abreu Martins ${ }^{1,3}$, Douglas da Silva Ferreira ${ }^{1,2}$, \\ Maísa de Carvalho Gonçalves ${ }^{1,2}$, José Eduardo Serrão ${ }^{1,4}$, Frederico Falcão Salles ${ }^{1,2}$ \\ ${ }^{1}$ Universidade Federal de Viçosa, Programa de Pós-Graduação em Entomologia, Viçosa, MG, Brasil. \\ ${ }^{2}$ Universidade Federal de Viçosa, Museu de Entomologia, Departamento de Entomologia, Viçosa, MG, Brasil. \\ ${ }^{3}$ Universidade Federal de Viçosa, Laboratório de Controle Biológico, Epamig Sudeste, Viçosa, MG, Brasil. \\ ${ }^{4}$ Universidade Federal de Viçosa, Departamento de Biologia Geral, Viçosa, MG, Brasil.
}

\section{A R T I C L E I N F O}

\section{Article history:}

Received 09 December 2020

Accepted 26 February 2021

Available online 26 March 2021

Associate Editor: Juliano Morimoto

\section{Keywords:}

Chorion

Hagenulinae

Mayfly

Taxonomy

\begin{abstract}
A B S T R A C T
The Hermanella complex is a well-established monophyletic group of Hagenulinae mayflies, but the phylogenetic relationships among its members are still being discussed. In order to fill some gaps in the taxonomy of this group we describe, for the first time, the eggs of eight species of this complex (Hermanella amere, Hermanella mazama, Hydromastodon sallesi, Hydrosmilodon gilliesae, Hydrosmilodon plagatus, Leentvaaria palpalis, Paramaka incognita, Paramaka sp.) using scanning electron microscopy, including some important members whose generic allocation have been questioned. The egg morphology in these eight species of Hermanella complex and their similarities with other species of the complex are discussed.
\end{abstract}

\section{Introduction}

The mayflies of the Hermanella complex, or Hermanellognatha, form a monophyletic clade of Hagenulinae (Ephemeroptera, Leptophlebiidae) with nymphs showing specialized filtering mouthparts, such as enlarged labrum, and rows of long setae on maxillae and labium (Domínguez and Flowers, 1989; Kluge, 2007). These insects have a wide distribution in the Neotropical region, with some representatives extending to the Nearctic region (Flowers and Domínguez, 1991).

The Hermanella complex was defined by Domínguez and Flowers (1989) and since then new genera and several new species have been described in this group. To date, approximately 40 species belong to this complex, including the genera Hermanella Needham \& Murphy, 1924, Hydromastodon Polegatto \& Batista, 2007, Hydrosmilodon Flowers \& Domínguez, 1992, Hylister Domínguez \& Flowers, 1989, Leentvaaria Demoulin, 1966, Needhamella Domínguez \& Flowers, 1989, Paramaka Savage \& Domínguez, 1992, and Traverella Edmunds, 1948.

\footnotetext{
* Corresponding author:

E-mail: thayna.raymundo@ufv.br (T.S. Raymundo)
}

Although taxonomic and phylogenetic studies about this group have increased considerably (e.g. Domínguez et al., 2001; Domínguez and Cuezzo, 2002; Sartori, 2005; Lima et al., 2012), some relationships are poorly understood. The monophyly of Hydrosmilodon was discussed by Sartori (2005), whereas Kluge (2007) suggest an unique genus, Hermanella, with five subgenera, with Hydrosmilodon and Paramaka as junior synonyms of Needhamella (a view not followed by Nascimento and Salles, 2013). Monjardim et al. (2020) have also found Hydrosmilodon as polyphyletic and, surprisingly, Hydromastodon was not recovered together with other genera of the Hermanella complex.

In a cladistic analysis performed by Domínguez and Cuezzo (2002), based on 5 genera and 11 OTU's (operational taxonomic units), egg characters were included in order to test their value to the analysis. The genera Leentvaria and Paramaka were not included, while Hydromastodon was not described by that time. In this study, the monophyly of the Hermanella complex was supported with new synapomorphies, including chorion sculptures, showing that egg characters are important in phylogenetic studies for the group. 
Considering that egg features are useful to understand the phylogeny of the Hermanella complex, data from additional species and genera may be useful to fill some gaps in future cladistics analysis. This study describes the chorion sculpture in the eggs of eight species from the Hermanella complex belonging to five genera, including Leentvaaria, Paramaka, and Hydromastodon.

\section{Materials \& Methods}

The insects (preserved in $80 \%$ ethanol) were obtained from collection kept in the Museu de Entomologia da Universidade Federal de Viçosa (UFVB), Brazil and identified with aid of taxonomic keys and comparison with original descriptions (Polegatto and Batista, 2007; Lima et al., 2012; Nascimento and Salles, 2013; Domínguez et al., 2014; Salles et al., 2016). The eggs were removed from the abdomen of mature nymphs or adult females of eight species from five genera. The eggs were transferred to $90 \%$ ethanol for $15 \mathrm{~min}$, hexamethyldisilazane for $10 \mathrm{~min}$ and air dried. Then the samples were fixed onto aluminum stubs, gold covered (20 nm thickness) and analyzed with a LEO VP1430 Scanning Electron Microscope at $15 \mathrm{kV}$ in Núcleo de Microscopia e Microanálise, Universidade Federal de Viçosa (UFV). Terminology used for egg descriptions follows Koss and Edmunds (1974).

\section{Results}

Hermanella amere Nascimento \& Salles, 2013 (Figs. 1a, 1b).

Egg size: $138-143 \mu \mathrm{m}$ in length, $50-100 \mu \mathrm{m}$ in width. General shape prismatic (Fig. 1a), pentagonal in cross section (Fig. 1b). Both polar regions concave. Chorion surface smooth or with small granules (Figs. 1a). Several knob-terminated coiled threads (KCT) in the concave polar region (Fig. 1b). Micropyle not visible.
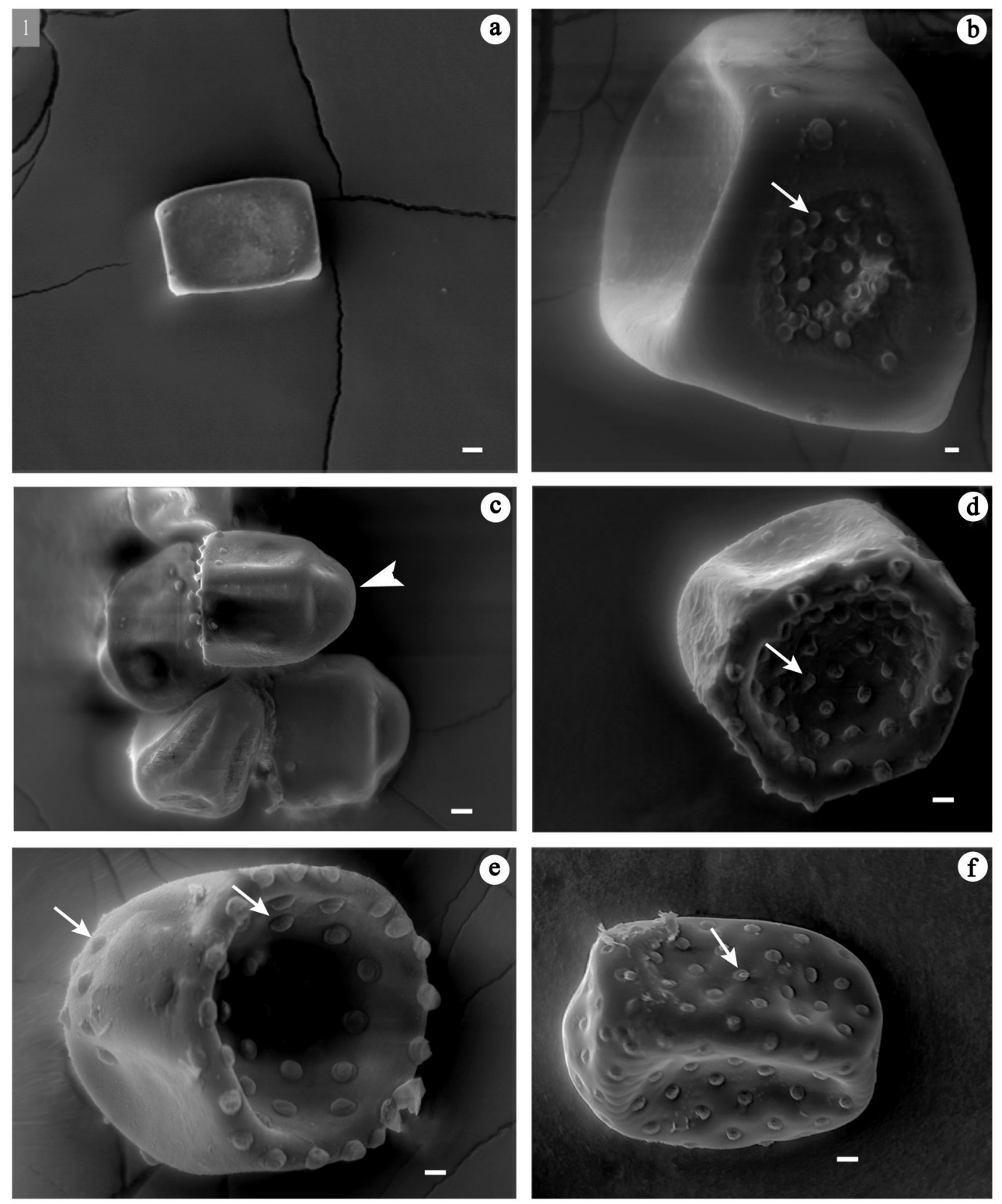

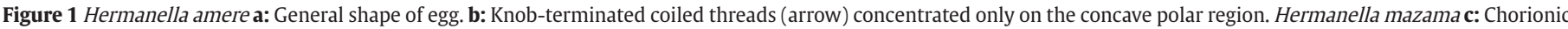

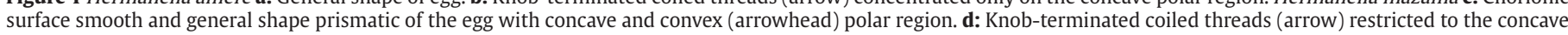

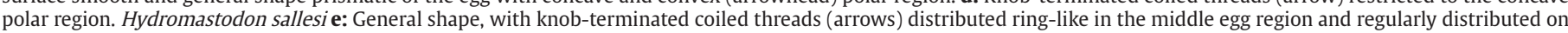

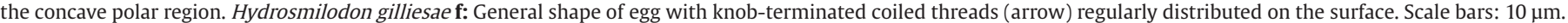


Material examined. Imago: Brazil, Espírito Santo State, Ibitirama, Cachoeira do Firmino, Rio Santa Clara, 20ํ35' 04” S / 41ํ3' 32” W, 720 m, 04.iv.2016, light trap, Ceunes col.

Hermanella mazama (Nascimento, Mariano \& Salles, 2012) in Lima et al. (2012) (Figs. 1c, 1d).

Egg size: $124-127 \mu \mathrm{m}$ in length, $55-115 \mu \mathrm{m}$ in width. General shape prismatic with a concave polar region (Fig. 1c), hexagonal in cross section (Fig. 1d), one concave and the other convex with some KCTs (Fig. 1c, 1d). Chorion surface smooth. Micropyle not visible.

Material examined. Subimago: Brazil, Espírito Santo State, Nova Venécia, Patrimônio do Bis, Rio Cotaxé, 18ㅇ3’ 27.5” S / 40ํ20’ 06.5” W, 20-21.xi.2012, pensilvania trap, E.M. Rozário, M.C. Gonçalves and K.B. Angeli cols.

Hydromastodon sallesi Pollegato \& Batista, 2007 (Fig. 1e).

Egg size: $120-136 \mu \mathrm{m}$ in length, $67-124 \mu \mathrm{m}$ in width. General shape prismatic, with one polar region convex, the other concave (Fig. 1e). Chorion surface smooth or with very fine small granules. KCTs distributed along a ring at the equatorial region and scattered in the on polar concave surface (Fig. 1e). Micropyle not visible.

Material examined. Nymph: Brazil, Rondônia State, Nova Londrina, Rio Urupá, 11ํ02’ 05” N / 62ํ0’ 34” W, 182 m, 02.ix.2012, N. Hamada col.
Hydrosmilodon gilliesae Thomas \& Péru, 2004 in Thomas et al. (2004) (Fig. 1f).

Egg size: $83-105 \mu \mathrm{m}$ in length, $67-124 \mu \mathrm{m}$ in width. General shape prismatic (Fig. 1f), quadrangular in cross section. Both polar regions flattened (Fig. 1f). Chorion surface smooth or with very fine small granules and KCTs regularly distributed on whole egg surface. Micropyle not visible.

Material examined. Imago: Brazil, Roraima State, Caracaraí, Cachoeira Bem Querer, 01 55’ 48.3” N / 6100'09.2” W, 71 m, 14.iii.2014, light trap, F.F. Salles col.

Hydrosmilodon plagatus Lima, Nascimento \& Salles, 2012 in Lima et al. (2012) (Figs. 2a-c).

Egg size: $195-200 \mu \mathrm{m}$ in length, $125-135 \mu \mathrm{m}$ in width. General shape oval, triangular in cross section (Figs. 2a, 2b). Polar regions flattened. Chorion surface with longitudinal costae and KCTs restricted to the polar regions (Figs. 2b, 2c). Circular area circa $35 \mu \mathrm{m}$ in diameter delimited by a narrow KCTs collar (Fig. 2b). Two micropyle in the equatorial area (Fig. 2a). Internal diameter of the micropyle 3-4 $\mu \mathrm{m}$. Circular opening micropyle smooth (Fig. 2a).

Material examined. Subimago: Brazil, Espírito Santo State, Nova Venécia, Rio Cricaré, 18³9’ 51.4” S / 40³0’ 44.9” W, 74 m, 18-19.ii.2013, pensilvania trap, E.M. Rozário, M.C. Gonçalves and K.B. Angeli cols.
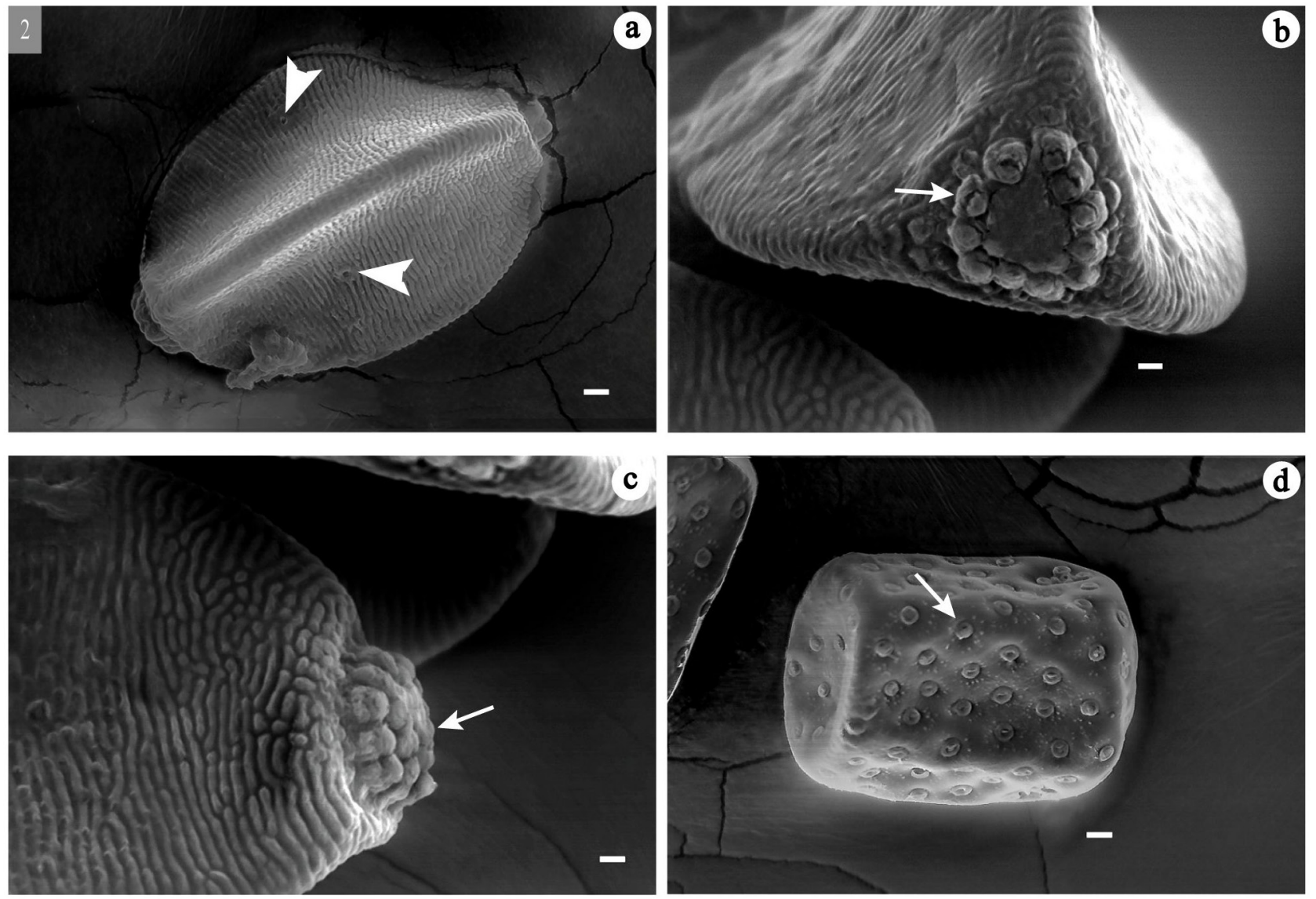

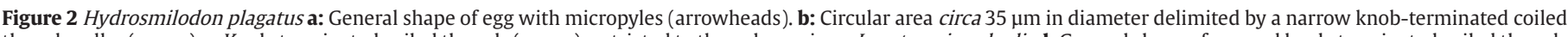

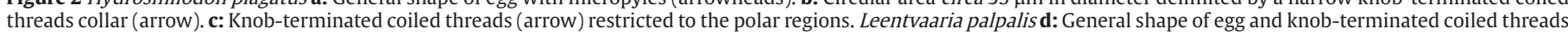
(arrow) regularly distributed on the whole surface. Scale bars: $10 \mu \mathrm{m}$. 
Leentvaaria palpalis Demoulin, 1966 (Fig. 2d).

Egg size: $90-100 \mu \mathrm{m}$ in length, $63-77 \mu \mathrm{m}$ in width. General shape prismatic (Fig. 2d), pentagonal to hexagonal in cross section. Polar and lateral regions concave (Fig. 2d). Chorion surface smooth or with very fine small granules. KCTs regularly distributed on whole egg surface, granulated. Each KCT rounded with wrinkles (Fig. 2d). Micropyle not visible.

Material examined. Imago: Brazil, Roraima State, Caracaraí, Cachoeira Bem Querer, $01^{\circ}$ 55' 48,3” N / 61 00' 09.2” W, 71 m, 09.ii.2007, light trap.

Paramaka incognita Domínguez, Grillet, Nieto, Molineri \& Guerrero, 2014 (Figs. 3a, 3b).

Egg size: $110-115 \mu \mathrm{m}$ in length, $96-115 \mu \mathrm{m}$ in width. General shape prismatic, circular to hexagonal in cross section (Fig. 3a). One polar region convex, the other concave. Chorion surface smooth. KCTs distributed along a ring at the equatorial region (Fig. 3a) and regularly distributed on concave polar region (Fig. 3b). Micropyle not visible.

Material examined. Imago: Brazil, Roraima State, Pacaraíma, Igarapé Miangue, 04.xi.2016, F.F. Salles and R. Boldrini, cols.

\section{Paramaka sp. (Figs. 3c-d).}

Egg size: $123-133 \mu \mathrm{m}$ in length, $96-124 \mu \mathrm{m}$ in width. General shape prismatic, circular to hexagonal in cross section (Figs. 3c, 3d). One polar region convex, the other concave. Chorion surface smooth. KCTs in the concave polar region (Fig. 3d). Circular area circa $110 \mu \mathrm{m}$ in diameter delimited by a narrow, continuous, irregular KCT collar (Fig. 3c). Micropyle not visible.

Material examined. Nymph: French Guiana, Takaritante, 04 37’ 18.6” N / 52ํ5' 38.2”, 35 m, 01-04.xi.2016, E. Domínguez and S. Clavier, cols.

\section{Discussion}

The general morphology of the eggs of the Hermanella complex was initially investigated by Domínguez and Flowers (1989), and since then some characteristics have been often encountered, such as polar regions flattened or slightly concave, terminal knobs of KCTs elevated above coiled thread, and a supraequatorial micropyle (Domínguez and Cuezzo 2002). The most of these characteristics are also present in the species here analyzed.

The eggs of He. amere and He. mazama with KCTs restricted to the polar egg region are similar to those found in Hermanella thelma Needham \& Murphy and Hermanella froehlichi Ferreira \& Domínguez (Figs. 1b and 3a in Domínguez and Cuezzo 2002). However, this feature is not exclusive for the genus because it also occurs in Hylister plaumanni Domínguez \& Flowers (Domínguez and Flowers 1989), Paramaka and Hydromastodon (present study).

The general pattern of the eggs of $L$. palpalis with KCTs regularly distributed on the whole egg surface and prismatic shape are also found in species of other genera, for example He. guttata Domínguez \& Flowers, N. ehrhardti (Ulmer), Hs. saltensis Flowers \& Domínguez (Domínguez and Cuezzo 2002), and Hs. gilliesae (present study). In phylogenetic studies Leentvaria has been claimed as the sister group
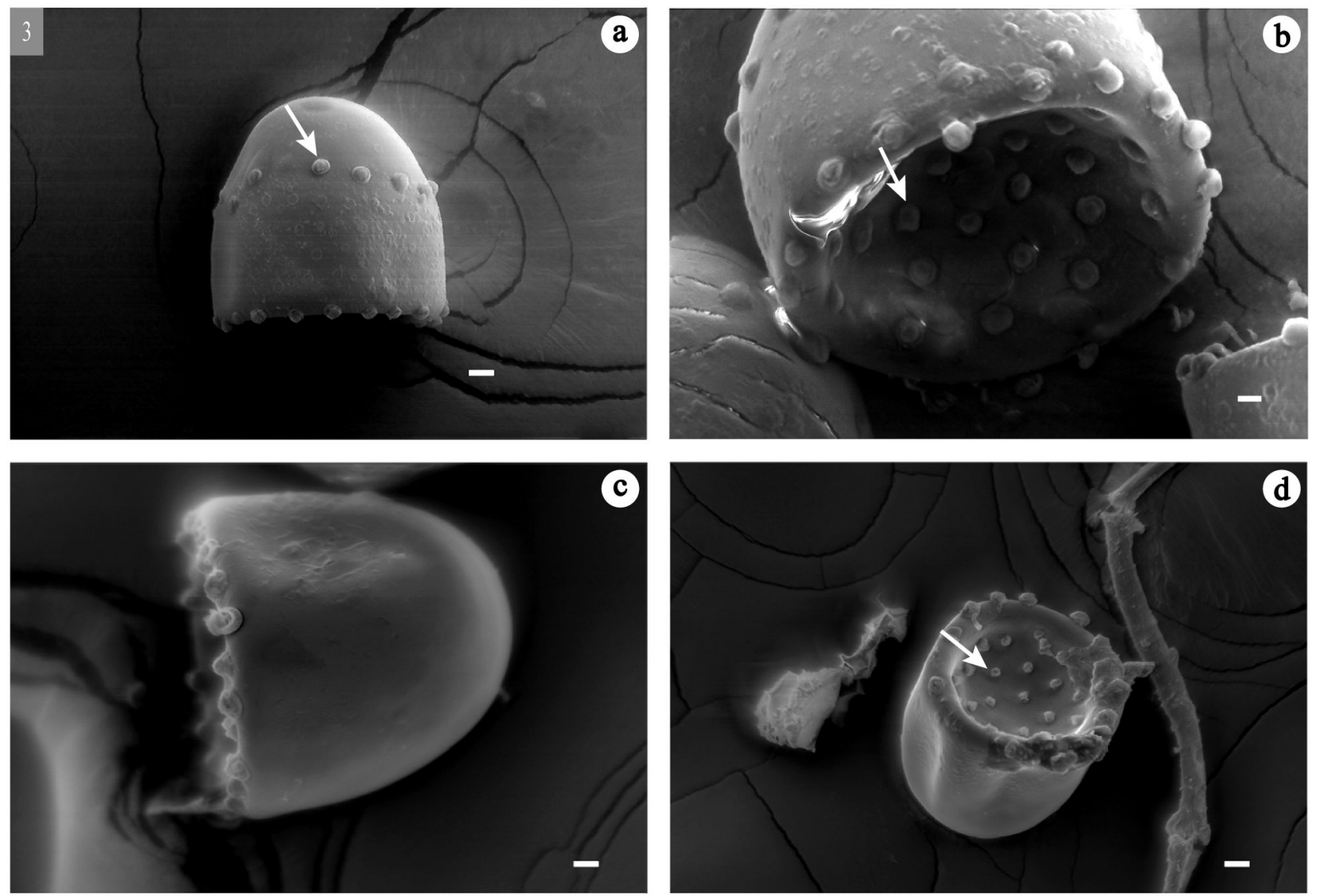

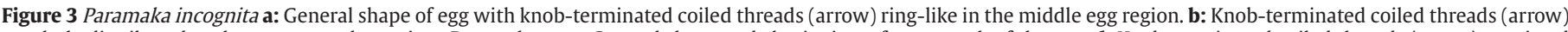

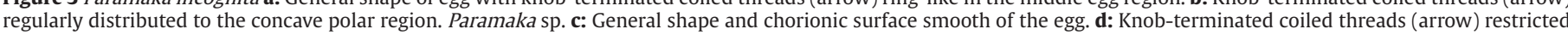
to the polar regions. Scale bars: $10 \mu \mathrm{m}$. 
of Needhamella ehrhardti (Domínguez et al., 2001) or Hs. gilliesae (Sartori, 2005). Salles et al. (2016) stated that some characteristics of the imago of L. palpalis are also found in Hs. gilliesae, suggesting that they are probably closely related, which is also suggested by the similar eggs features found here.

The chorion sculpture in the eggs of Hs. gilliesae is also similar to that found in Hs. saltensis, except the occurrence of granulated bumps in the later (Domínguez and Cuezzo, 2002). The egg morphology of Hs. plagatus is different from the general pattern found in other Hydrosmilodon species, and even in the Hermanella complex, what gives additional evidence to the non-monophyletic nature of Hydrosmilodon (see Salles et al., 2016).

We also presented the first egg description for Paramaka ( $P$. sp. and P. incognita), and for Hydromastodon (Hm. sallesi). The eggs of these species are similar, with circular-shape, hexagonal in cross section, one polar region concave with KCTs and the other convex, smooth. Paramaka incognita and $\mathrm{Hm}$. sallesi have also KCT distributed along an equatorial ring, a characteristic not found in any other representative of the Hermanella complex. Further studies are still necessary to verify if these are closely related genera.

This study describes for the first time the eggs of Leentvaaria, Paramaka, Hydromastodon and of additional species in Hydrosmilodon and Hermanella. Overall, our findings provide new data with potential to enhance the knowledge about the systematics of the Hermanella complex.

\section{Acknowledgments}

We are grateful to Laboratório de Ultraestrutura Celular and to Núcleo de Microscopia e Microanálise of Universidade Federal de Viçosa (UFV) for the support in carrying out this research. This study was financed in part by the Coordenação de Aperfeiçoamento de Pessoal de Nível Superior (CAPES) to TSR (process \# 88882.349605/2019-01), to JLAM (process \# 88882.349600/2019-01), to DSF (process \# 88887.372018/2019-00), to MCG (process \# 88887.371937/2019-00) and by the Conselho Nacional de Desenvolvimento Científico e Tecnológico (CNPq) to FFS (processes \# 305847/2015-5 and 309666/2019-8).

\section{Conflict of interest}

The authors declare no conflict of interest.

\section{Author contributions}

TSR conceived the research, made the egg descriptions, improve the images and wrote the document. JLAM supported the egg descriptions and helped the work in the laboratory. DSF made the plates, supported the laboratory work and made the measures of the eggs. MCG helped to describe the eggs. JES facilitated the optic equipment for took the SEM micrographs, improved the eggs descriptions and the final version of this paper. FFS improved the introduction and discussion of the document. All authors critically reviewed the manuscript and accepted the final version of this paper.

\section{References}

Domínguez, E., Cuezzo, M. G., 2002. Ephemeroptera egg chorion characters: a test of their importance in assessing phylogenetic relationships. J. Morphol. 253, 148-165. https://doi.org/10.1002/jmor:1117.

Domínguez, E., Ferreira, M. J., Nieto, C., 2001. Redescription and phylogenetic relationships of Leentvaaria Demoulin (Ephemeroptera: Leptophlebiidae). In: Domínguez, E. (Ed.), Trends in Research in Ephemeroptera and Plecoptera. Kluwer Academic/Plenun Publishers, New York, pp. 313-320. https://doi.org/10.1007/9781-4615-1257-8_35.

Domínguez, E., Flowers, R. W., 1989. A revision of Hermanella and related genera (Ephemeroptera: Leptophlebiidae; Atalophlebiinae) from Subtropical South America. Ann. Entomol. Soc. Am. 82, 555-573. https://doi.org/10.1093/aesa/82.5.555.

Domínguez, E., Grillet, M. E., Nieto, C., Molineri, C., Guerrero, E., 2014. Ephemeroptera from the Venezuelan Guayana's Uplands: Families Leptophlebiidae, Euthyplociidae and Oligoneuriidae. Zootaxa 3827 (3), 301-317. https://doi.org/10.11646/zootaxa.3827.3.1.

Flowers, R. W., Domínguez, E., 1991. Preliminary cladistics of the Hermanella complex (Ephemeroptera: Leptophlebiidae: Atalophlebiinae). In: Alba-Tercedor, J., Sanchez-Ortega, A. (Eds.), Overview and Strategies of Ephemeroptera and Plecoptera. Sandhill Crane Press, Gainesville, 49-62.

Kluge, N. J., 2007. A new taxon Hermanellonota, or subtribe Hermanellini subtr.n. (Ephemeroptera: Leptophlebiidae: Hagenulini), with description of three new species from Peruvian Amazonia. Russ. Entomol. J. 16 (4), 127-137.

Koss, R. W., Edmunds, G. F., 1974. Ephemeroptera eggs and their contribution to phylogenetic studies of the order. Zool. J. Linn. Soc. 55, 267-349.

Lima, L. R. C., Nascimento, J. M. C., Mariano, R., Pinheiro, U. S., Salles, F. F., 2012. New species and new records of Hermanella complex (Ephemeroptera: Leptophlebiidae) from Eastern Brazilian Coast. Ann. Limnol. 48, 201-213. https://doi.org/10.1051/limn/2012011.

Monjardim, M., Paresque, R., Salles, F. F., 2020. Phylogeny and classification of Leptophlebiidae (Ephemeroptera) with an emphasis on Neotropical fauna. Syst. Entomol. 45, 415-429. https://doi.org/10.1111/syen.12402.

Nascimento, J.M.C., Salles, F.F., 2013. New species of Hermanella complex (Ephemeroptera: Leptophlebiidae) from brazilian atlantic forest. Zootaxa. 3718 (1), 1-27. http://doi.org/10.11646/zootaxa.3718.1.1.

Polegatto, C. M., Batista, J. D., 2007. Hydromastodon sallesi, new genus and new species of Atalophlebiinae (Insecta: Ephemeroptera: Leptophlebiidae) from West and North of Brazil, and notes on systematics of Hermanella group. Zootaxa 1619, 53-60.

Salles, F. F., Dominguez, E., Mariano, R., Paresque, R., 2016. The imagos of some enigmatic members of the Hermanella complex (Ephemeroptera, Leptophlebiidae). ZooKeys 625, 45-66. https:// doi.org/10.3897/zookeys.625.9874.

Sartori, M., 2005. A new species of the genus Paramaka Savage \& Domínguez, 1992 with some comments on related genera (Ephemeroptera, Leptophlebiidae, Atalophlebiinae). Stud. Neotrop. Fauna Environ. 40 (3), 237-245. https://doi.org/10.1080/01650520500208481.

Thomas, A., Boutonnet, J., Péru, N., Horeau, V., 2004. Les Éphémères de la Guyane Française. 9. Descriptions d'Hydrosmilodon gilliesae n. sp. et d'H. mikein. sp. (Ephemeroptera, Leptophlebiidae). Ephemera 4, 65-80. 